\title{
Mutual-mothering as wise living or living wisely
}

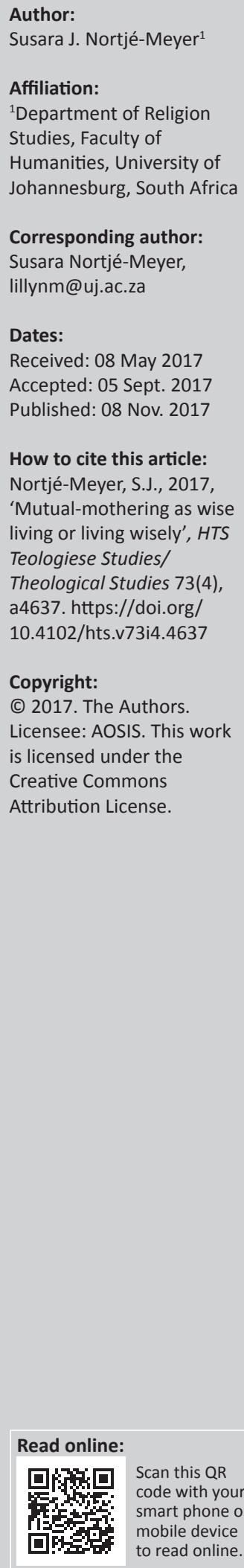

In the 1970s, feminist biblical scholars began to conduct research on the biblical traditions of wisdom and the manifestation of female images of God, named Sophialogy. There are different focus areas within Sophialogy, but the formulation of Wisdom/Sophia goals for liberation and equality was inter alia the focus area of feminist biblical interpretation. According to this approach, Jesus as the prophetic messenger of Wisdom/Sophia activates the Sophia tradition through his works or deeds of compassion for the poor, the outcasts, and all those suffering from injustice. Women in Africa interpret these deeds as communal 'wise living' and the custodians of justice. This culminates in a motherhood agenda, namely, making peace for life; ensuring mutual respect, honour and care for life; looking for fairness; reciprocity; wholeness and inclusiveness. The aim of this paper is to discuss mutual-mothering in the African context as an ethos for living wisely and justly. Having instincts to care and to protect are not exclusively female attributes, but include also males.

\section{Introduction}

Most societies and religions have integrated a well-defined moral system or èthos. These systems are reinforced by cultural and religious traditions, as well as Holy Scriptures. Ethos [or character] refers to habitor custom; it involves the highest moral goal for humans in a society and the best way they can arrange their common life to be able to achieve that goal. It is to:

develop the moral skills and virtues that would enable people to be good citizens, that is, to know one's place in a stratified society, and to live according to its rules, expectations, and interests. (MacIntyre 1966:57-83; Meeks 1993:40; Mouton 2014:165, ftn 2)

Mouton says that contemporary theologians, philosophers and social scientists have become increasingly concerned about the formation of moral people. However, the fundamental ethical concern for many people, including theologians, is now one of identity: 'It is believed that who people are will determine what they see as moral challenges, and how they will respond' (Mouton 2014:165). This moral framework is determined by what is called 'communities of character', namely the household, locality, religious institution, educational organisation, and workplace in which they live, where they practise specific virtues and act ethically (MacIntyre 1984).

To be able to reach the highest moral goal in any society, an ethics of responsibility needs to be developed. Schüssler-Fiorenza (2011) argues that communities of character, as powerful social networks, can provide the necessary stability and safety in the lives of their people in terms of justice and well-being. But how can this happen in a world characterised by abuses of power, corruption and conflict? How can communities of character be formed as the embodiment of an alternative èthos? And what influence can communities of character have on their society?

The household as a community of character in the African context is a powerful social network that can provide society with justice and well-being. Furthermore, the African household is shaped by the significance of womanhood and the Ubuntu spirit that is found in the community. ${ }^{1}$ African motherhood is characterised by values of love, harmony, peace and cooperation (Amadiume 1997:102,122). I propose mutual-mothering in the African context as a hermeneutical principle for living wisely and justly. Mutual-mothering, for me, embodies wisdom; therefore, I want to link the idea of mutual-mothering to wisdom as it has been associated with the figures of Wisdom/Sophia, Isis and Ma'at, and the role of mutualmothering in the African context.

1.Ubuntu advocates an ancient African worldview or philosophy that could be critically applied to shape modern societies (Broodryk 2007) 


\section{The concept of mutual-mothering}

The concept of mutual-mothering refers to non-maternal care by any group member other than the genetic mother. It involves extended care and can be undertaken by any woman or man or even other children in the group. It comprises a wide variety of behaviours, including but not limited to provisioning, nursing, protecting, mentoring, touching and carrying. It is not only characteristic of humans but also a widespread phenomenon among mammals and birds and is particularly common among the Primate order (Hardy 2009).

The idea is to develop a new language and model that describe developments from a relational perspective, especially the idea of mutual-mothering. Women's experiences more often involve new connections and relationships which may or may not transform older connections.

A psychology of relationships and relational development stresses the importance of connection, where the self is not the primary core element but the energy of the person and group development (Jordan et al. 1991). By 'growing into connection', I mean the growing sense that a person can represent oneself freely in relationships which hold, sustain and foster the development of all participants. This impacts positively the expanding network of relationships and for the ways in which individual relationships exist within a whole relational context.

Mutuality is a key concept for all healthy connections. This is not the equivalent of equality, reciprocity or intimacy but rather describes a way of being: where both or all participants can be authentically present, able to freely represent their feelings, thoughts and perceptions with movement towards greater spaciousness, clarity and clearer manifestations of individual differences. Connections maintained by domination, suppression, denial or distortion, or that are selective in attention, are not authentic and not appropriate. Healthy connections involve a willingness to continually adapt to change and to accept the fact that sometimes the individual does not yet understand or is not being understood (Gilligan \& Rogers 1993:115).

Gilligan and Rogers (1993:116) discuss three dynamic interactive processes that motivate the direction towards positive connection and in this case are defined as mutual mothering.

Mutual engagement: This describes the shared interest, attentiveness, joining and focusing together and engaging in a shared process through interaction.

Mutual empowerment: This involves a mutual sense of activation and empowerment and describes a power-with, power-together or a power-through interaction. Mutualmothering is a kind of power that can be refined to make it possible for women as well as men to 'mother'.

Mutual empathy and authenticity: This entails a mutual desire to understand experiences and thereby increases and builds authenticity. Authenticity and empathy are inextricably interconnected, and both are necessary for relational development. True dialogue involves two voices listening and responding. In the absence of mutual authenticity, only one voice will be dominant and the other silenced (Gilligan \& Rogers 1993:116). Empathy is a complex psychological capacity requiring a combination of cognitive and emotional knowing. It requires a capacity to stretch one's own experience to accept and join with the other. Mutual empathy is based on the mutual capacity to receive, accept and understand the other.

This notion of mutual-mothering can be linked to SchüsslerFiorenza's (2009:4) discussion of the principle of wisdom: 'Wisdom is a state of the human mind and spirit characterised by deep understanding and profound insight'. She says that wisdom is a perception of wholeness that does not lose sight of particularity, relativity and the intricacies of relationships. Wisdom understands complexity and seeks integrity in relationships. It is usually seen as bringing together selfawareness and self-esteem with the awareness and appreciation of the world and the other.

\section{Wisdom associated Wisdom/ Sophia, Isis and Ma'at}

The discussion of Sophialogy, or the rediscovery and recreation of the submerged traditions of wisdom in biblical texts, has influenced feminist acts of interpretation and theology significantly over the past two decades. The possibility that Jesus could be identified with the figure of Wisdom/Sophia made it obvious for feminists to utilise the opportunity to define a legitimate female deity, or Divine Wisdom (goddess), within Christian theology. ${ }^{2}$ The motivation here is the ongoing search for a source for a more just, more balanced and more compassionate and inclusive society.

Wisdom, as a divine female figure, is represented by a variety of goddesses and goddess myths in biblical and extra-biblical traditions. Although the feminist scholarly search for the trajectory of Wisdom/Sophia in biblical writings encounters a host of historical and theological problems, it is nevertheless commonly accepted that the biblical image of Wisdom/ Sophia has integrated goddess language and traditions. When following the debate, it seems there is no consensus among biblical scholars that Jesus can be understood as the personification of the female Wisdom/Sophia or that a goddess myth is the matrix for the wisdom sayings in the New Testament. However, there are many Jewish-Hellenistic and Christian traditions that could have an influence on Wisdom/Sophia Christology (Robinson 1975).

Schüssler-Fiorenza (2009:3-4) summarises the meaning of the word wisdom in biblical as well as in contemporary religious discourses as having a double meaning: 'It can either refer to

2.Central to Sally Douglas (2016) discussion is whether Jesus uniquely embodies the divine female. Douglas provides textual evidence of New Testament language associated with the female divine in relationship to Jesus to propose the occurrence of wisdom Christology and wisdom soteriology in early Christian writings. 
a quality of life and of a people and/or it can refer to a figuration of the Divine'. Wisdom is the practical knowledge gained through experience and daily living as well as through the study of creation and human nature. Both word meanings, that of capability (wisdom) and that of female personification (Wisdom/Sophia), are important for formulating a feminist/ womanist biblical approach for interpretation. Biblical traditions cannot claim exclusivity of the word wisdom or the concept of Divine Wisdom. It is found in the thoughts and writings of all known religions. It is trans-cultural, international and inter-religious.

Jewish theology explains the concept of wisdom as a poetic personification of a divine function or wisdom as a myth in its own right. The first suggests that wisdom developed as a poetic personification, an abstract concept rather than a real personal being. Wisdom cannot be explained merely as a metaphorical personification of certain attributes of Yahweh. Historians of religion suggest that the figure of Wisdom has its explanation in reference to a foreign mythical goddess(es), e.g. Ishtar, Ma'at, Isis, Aphrodite, Psyche, Demeter and Kore (and perhaps Artemis) (daCosta 2002:86).

Schüssler-Fiorenza's (1975:29) analyses of Ecclesiastes 24:3ff. reveal that the mixing of motives is central to the wisdom figure. Since this wisdom figure exists only in a syncretistic form, it is methodologically impossible to look for the ancestry of one goddess, Wisdom, and her myth. Instead, we must look first for the goddess with her myth and then search for the mythical revision of it in Jewish theology. The goddess most widely honoured at the time is Isis. Isis and her myth are suggested as standing behind the wisdom hymn in Ecclesiastes 24 . The text shows that personified wisdom belongs not to a stage of myth (mythic material) but to mythology (reflective mythology). Its predecessor is the syncretistic goddess, which is most widely known under the name of Isis.

In Proverbs 1-9 we can observe 'reflective mythology' assuming a living myth (retold stories), namely that of the Egyptian goddesses Ma'at or Isis. But it seems that mythical material was added to older collections of Jewish wisdom sayings that had no reference to a mythical figure of wisdom. Adding wisdom material of the myth of Ma'at or Isis confirmed Jewish faith in the wisdom of Yahweh as Lord of creation and redemption. The relationship between the original living myth and wisdom mythology in Judaism is therefore not that of background or influence, but that of theological reflection which uses the language and features of myth in the mode of reflective mythology. For example, the author of the Wisdom of Solomon patterned his book according to the structure of the Isis aretalogies ${ }^{3}$ (Goodenough 1935:7; Schüssler-Fiorenza 1975:33).

The trajectory of reflective mythology appears to have borrowed primarily from the myth of Isis but could also have

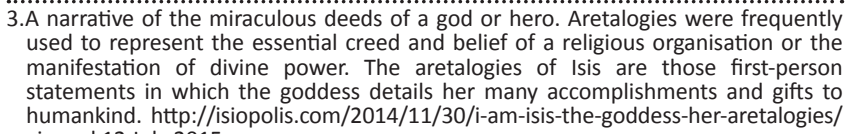
statements in which the goddess details her many accomplishments and gifts to humankind. http://isiopolis.com/2014/11/30/i-am-isis-the-goddess-her-aretalogies/ viewed 12 July 2015 taken over elements of other goddess myths. Instead, mythological language is probably developed in dialogue with various mythic beliefs and thought-contexts of the time. There is not one correct interpretation of the Wisdom/Sophia or the goddess cults. Its strength lies in the plurality of meanings (daCosta 2002:86; Schüssler-Fiorenza 1975:38).

\section{Isis cult $\mathbf{t}^{4}$}

Isis was worshipped as the goddess of navigation, a deliverer from struggles and crises, the goddess of heaven, the mother of the universe, and she was identified with wisdom (Balch 2003; Koester 1982). Scholars see Isis and Wisdom/Sophia in close relationship and even implicate that Isis is the principle goddess of Wisdom/Sophia. In comparison, Jewish-Hellenistic wisdom speculation conceives Wisdom/Sophia as a heavenly figure (Job 20; Prov 1-9); she is pre-existent (Prov 8:22-31; Job 28:25-27; Eth Enoch 42:1-3; Ec 24:1-12; Wisd of Sol 7:21-26); participates in creation, lives in close union with God and seeks to dwell among humans; a variety of sexual images are also applied to Wisdom, namely she is mother-wife, lover and beloved, virgin and bride. Feminist studies have argued that post-exilic women in Israel and Hellenistic Jewish women in Egypt perceived Divine Wisdom as prefigured in the language and image of Egyptian (Ma'at, Isis) and Greek (Athena or Diké, Artemis ) goddesses (Schüssler-Fiorenza 2009:4-5).

Goodenough (1935:45) has noted that no matter how different each goddess was in detail; all were celebrated with common elements. Goodenough noted these common elements as being the Great Mother, the Female Principle and the Universal Queen. However, feminists are suspicious about these stereotypical and essential characteristics attributed to the female goddesses and Wisdom/Sophia, and insist that these goddesses represent much more than essential female elements. If the essential female elements are sustained, this will imply maleness with transcendence and superiority, while femaleness will be associated with immanence and inferiority. Qualities such as nurturing and tenderness are not only capacities of women but also of men (cf. DeaneDrummond 1997:21). Furthermore, female imagery of the divine should not only be nurturing but also powerful, initiating, creating-redeeming-saving and victorious over the powers of this world (cf. Johnson 1992:54). Blenkinsopp (1995:47) notes that Isis, as the 'embodiment of Ma'at the principle of cosmic and social order, maintains justice, ordaining laws for humanity and filling the world with good order and righteousness'. Besides, it would be a serious misconception to glorify the mothering attributes of the female goddesses, as the myth of Isis and Osiris demonstrates.

\section{The African context}

The Egyptian goddess Ma'at is regarded as the embodiment of law and order and is also perceived to represent the

4.From $400 \mathrm{BCE}$ to $400 \mathrm{CE}$ the Egyptian religious movement that worshipped Isis and Osiris was thoroughly hellenised and spread throughout the Greco-Roman Empire. Eventually it was transformed into the worship of Isis and Sarapis. Bricault's (2001) atlas lists over 167 Isis sanctuaries that were scattered from Africa to Palestine, atlas lists over 167 Isis sanctuaries that were scattered from Africa to Palestine,
Syria, Asia Minor, Greece, Italy, France (Gaul), the Balkans, Britain and Spain during this time. 
intrinsic link between the physical and the spiritual (a harmonious cosmological worldview). ${ }^{5}$ The Ma'at belief system is a code of conduct for the goddesses and the gods, to which a person must adhere to in order to achieve a goddess- or god-like state. There is much debate among Egyptologists as to whether Ma'at is an 'actual' goddess or only the personification of a concept.

According to Broodryk (2007:41), the Netchar (called the code of conduct) of Ma'at was associated with the seven cardinal virtues of truth, justice, propriety, harmony, balance, reciprocity and order (Broodryk 2007:42; Koka 2002:10). Furthermore, proponents of Ubuntu link Ubuntu core values (community; respect; seriti/isithunzi [vital/moral force]; sharing; caring; belief in a divine world) to the values of the Egyptian principles of morality enshrined in the forty prescriptions or admonitions of Ma'at. Dyrness (1990:42-52) claims that these Ubuntu values are found in many if not all sub-Saharan societies.

African scholars such as Amadiume (1997), Isichei (2005) and Muthien (2008) have documented the existence of the notion of goddesses in various societies and diverse contexts in Africa. The consideration of constructing a female deity, known as the 'Great Mother' (Armstrong 2010:20) in various parts of Africa and the world, forms the essence of the 'Mother Goddess'. Amadiume (1997:102) states that in Africa, especially in Nigeria and West Africa, mothers were considered sacred and held unlimited authority. The presence of the goddess, Ala, known as the Earth Spirit, also confirms such a 'mother' construct in this society (Amadiume 1997:182). This goddess reigned above all deities and ancestors, and the python was her sacred symbol. In addition, the elderly women among the Nnobi were the custodians of goddess worship; they led the community to resist all efforts from Christian missionaries to undermine the worship of the goddess, Idemili, named after the river Idemili (Amadiume 1987:121-122). ${ }^{7}$ Various goddess societies used a snake and water as a symbol of immortality because it represented rebirth and regeneration; it was also associated with wisdom and was perceived to be in touch with the earth (Ferguson 1995:69).

\section{Nurturing and mothering}

Iseke and Ozuduke (2011) and Nwoye ([s.a.]) show that conceptions of African womanhood, which share the elements of Ubuntu, namely, justice, mutual respect, inclusivity and tolerance, have been at the forefront of peace building and conflict resolution in past and present African societies. According to Chidam'modzi (1994/5:46), African

5.She embodies law, order, rule, truth, right, righteousness, canon, justice straightness, integrity, uprightness and the highest conception of physical and moral law known to Egyptians (Bhengu 2006:19).

6.The earliest surviving text found that mentions Ma'at date from 2780 to $2250 \mathrm{BCE}$. The only known temple dedicated to Ma'at which has been found so far appears in the Karnak Complex of Thebes (Luxor). Texts indicated that other temples to her may have existed at Memphis and Deir el Medina but have not been found. http:// www.shira.net/egypt-goddess.htm viewed 07 Jul 2015.

7.Such resistance, according to Amadiume, was demonstrated in two separate incidents: when the British colonial power banned goddess worship and when one Christian missionary killed a python. womanists have conceptualised womanhood, wifehood or motherhood in unique ways. For them, being an African woman/mother is perceived as the pride of being a female human being.

Therefore, African womanism focuses on the concepts of African motherhood and womanhood. Womanhood, named Bosadi by Masenya (1997), is characterised by the significance of the African family and the Ubuntu spirit that is found in the community. African motherhood is characterised by values of love, harmony, peace and cooperation, no bloodshed, and self-sacrifice (Amadiume 1997:102, 122). This approach holds the promise of a greater inclusivity and representation, encompassing Africa and other third worlds, and their cultural uniqueness. It also brings to the forefront the role of African mothers as leaders in the struggle to regain, reconstruct and create a cultural integrity that promotes the ancient Ma'at principles of reciprocity, balance, harmony, justice, truth, righteousness and order (Dove 1998:535). The African womanist approach encapsulates a unique contextual and cultural hermeneutic, emphasising ideological critique from the experience and perspective of African women to address women issues in Africa specifically (Njoroge 2005:35-37).

African womanists do not perceive the African male as the opponent. They are of the opinion that the African male does not have the same institutionalised power as their white counterparts to oppress African women in the same way, but they are opposing patriarchy (Hudson-Weems 1998:22-25). They also argue that the concepts of African motherhood give African women the status and position to influence society positively because women are the ones assigned the nurturing role in the community. These women no longer view motherhood as victimising women but as empowering women and people in their communities (Bisscoff 2009:170-171; Oyěwùmi 2003:12-13).

In the context of Africa, all women are considered mothers, even if they do not have their own biological children. The communal nature of African societies leads to women, and men, taking on parental roles which can also be nonbiological. Obioma Nnaemeka (1997:5) points out that motherhood has become associated with victimhood as a result of linking motherhood as an institution with motherhood as an experience. The difference is that patriarchy constructs the institution of motherhood while women experience motherhood. However, Nnaemeka states that African feminist views of motherhood have shifted in the past decade in terms of articulating the affirmative aspects of motherhood while separating motherhood from victimhood. Fundamentally, motherhood is not constructed in relation to or in opposition to fatherhood; it is regarded in its own right. Mothers are perceived as especially powerful - literally and mystically, in regard to the well-being of the community. Thus, motherhood can also be seen as a choice and an experience, with its pain and rewards, and in the same way, the abandonment of motherhood can be an act of freedom and self-determination for women (Bisscoff 2009:170-171). 
Furthermore, African women have lived in the context of 'corporate' and 'dual sex's cultural traditions. The concept of 'corporate' refers to the fact that individuals are part of many interdependent human relations in the family and the community. The 'dual sex' system refers to the practice among the Igbo people that allows women to participate in rituals and some other tasks in society (Mikell 1997:3, 11-12; Okonjo 1976). According to Amadiume (1987:42, 59; cf. Okonjo 1976), the 'dual sex' roles of 'male daughters' and 'female husbands', which are unique to Africa, create and allow equal space and participation for women in the community. The 'male daughters' were equal leaders and exercised more power in their community. 'Female husbands' practised woman-to-woman marriages in two contexts, namely, the context of either a childless marriage or of rich and powerful women exercising their wealth and power (cf. Amadiume 1987:72; Oyěwùmi 2003:16).

\section{Conclusion}

There is not one correct interpretation of the Wisdom/Sophia or goddess cults. Its strength lies in the plurality of meanings (daCosta 2002:86). One way in which Isis's sustaining relationship to the Pharaoh and all of Egypt is expressed through the motif of nursing. Isis's nurturance of the Pharaoh reflects her specific political role but also indicates sustenance in general, since the Black Land, the part of Egypt that is covered by the Nile inundation and therefore feeds the nation, is also represented in Isis (LiDonnici 1992:408). According to the Wisdom of Solomon 7:24-27f., wisdom dwells with those who seek for her and belong to the righteous and elect ones. Jesus as the prophetic messenger of Wisdom/Sophia activates the Sophia tradition through his works or deeds of compassion for the poor, the outcasts and all those who are suffering from injustice. ${ }^{9}$ Women in Africa interpret these deeds of compassion as communal 'wise living' and are the custodians of justice. This culminates in a motherhood agenda, namely making peace for life; ensure mutual respect, honour and care for life; looking for fairness; reciprocity; wholeness and inclusiveness. For example, the Shona and Ndebele cultural discourse celebrates mothering/motherhood as the defining centrepiece of African-centred existence. Within this paradigm other life-furthering values associated with mothering/ motherhood are family-centeredness, male compatibility, flexible role playing, adaptability and strength. These values are all outlined and explicated in the theory of African womanism (Muwati et al. 2011:1). This theory of African womanism confirms that the Ubuntu's power stems from its ethical spiritual commitment, its propensity to value humility and human dignity, and not from its capacity to impose a set of values on another. As discussed above, the world is acquainted with the values of care and compassion, but it seems the wisdom to apply these values is, so far, deficient.

According to Pavel Florensky, wisdom is the fruit of living religious consciousness, rather than the invention of

\section{A term coined by Ökonjo (1976)}

9.The line of sages who have received the truth (wisdom) culminates in John the Baptist and Jesus (cf. Lk 11:49-51). philosophical speculation (cf. Slesinski 1984:169). 'Wise living' is articulated in Schüssler-Fiorenza's (2009) discussion of the principle of wisdom. She says:

Wisdom is a state of the human mind and spirit characterised by deep understanding and profound insight. It is elaborated as a quality possessed by the sages but also treasured as folk wisdom and wit. Wisdom is the power of discernment, deeper understanding, and creativity; it is the ability to make connections, and to learn from experience. Wisdom is intelligence shaped by experience and sharpened by critical analysis. It is the ability to make sound choices and incisive decisions. (p. 4)

Schüssler-Fiorenza continues by saying that wisdom is different from intelligence, in the sense that a person is not born with wisdom. It is acquired by lived experiences. It is a perception of wholeness that does not lose sight of particularity, relativity and the intricacies of relationships. Wisdom understands complexity and seeks integrity in relationships. It is usually seen as bringing together self-awareness and selfesteem with the awareness and appreciation of the world and the other. Wisdom is neither a specialised discipline nor a discrete field of study. It is a radical democratic concept insofar as it does not require extensive schooling and formal education. Unschooled people can acquire wisdom and highly educated people might lack it.

Catherine Keller has introduced the idea of emancipatory wisdom. She insists that the biblical notion of wisdom is linked to the principle of social justice for the poor and vulnerable in the community and, therefore, should be prevented from becoming a version of spiritual individualism (Keller 1991:143).

According to Bisschoff (2009:18), Western women incline to emphasise individual emancipation and self-determination, while African women tend to concentrate on an emancipated public participation within their communal and broader societal spheres, emphasising complementarity and cooperation between women and men (cf. also Mikell 1997:3-10). Care, protection and nurturing are not essential to women; they are essential to human beings and therefore essential to men as well. A good example is the meaning of the name 'father' for God in the Gospels. His loving attention and divine care for the world was seen in Jewish Wisdom literature as embodying and made present in the figure of Divine Sophia. Unfortunately, this sophialogical determination and qualification of the father title for God has been completely lost in Christian thought. Instead, the theological understandings of Philo, John and other Jewish and early Christian writers have determined the androcentric meaning of father and eventually eliminated Wisdom/Sophia from NT Christology (cf. Schüssler-Fiorenza 1994:154).

According to Eisler (1988:xix), all societies are patterned after either the 'dominator model' in which human hierarchies are ultimately backed up by force or threat of force, or the 'partnership model' which is supported through equal cooperative effort. How these relationships are structured has definite effects on the lives of women and men, and of course, on society as a whole. I call this 'cooperative effort' 
mutual-mothering to emphasise the deep human connection and affection that societies should demonstrate in their 'interconnectedness-towards-wholeness', as Krog (2008:361) articulates it. Agnes Rafferty calls this a theology of relationships referring to relationality, friendship, and compassion. (2001:112). Rafferty is of the opinion that relationality is the 'stuff of the universe' that needs to be a central component in any performance of culture, particularly in religious rites and may point to a way forward (2001:105).

The aim of this paper is to propose mutual-mothering in the African context as an ethos for living wisely and justly. As I have argued, having instincts to care and to protect are not exclusively female attributes but are intrinsically human, and therefore intrinsically also an element of the male identity.

\section{Acknowledgements Competing interests}

The author declares that she has no financial or personal relationships which may have inappropriately influenced her in writing this article.

\section{References}

Amadiume, I., 1987, Male daughters, female husbands: Gender and sex in an African society, Zed, London.

Amadiume, I., 1997, Re-inventing Africa: Matriarchy, religion and culture, Zed, London.

Armstrong, K., 2010, The case for God. What religion really means, Vintage Books, London.

Balch, D., 2003, 'The suffering of Isis/lo and Paul's Portrait of Christ Crucified (Gal. 3:1): Frescoes in Pompeian and Roman Houses and in the Temple of Isis in Pompeii', The Journal of Religion 83, 24-55. https://doi.org/10.1086/491222

Bhengu, M.J., 2006, Ubuntu: The global philosophy for humankind, Lotsha, Cape Town.

Bisscoff, L., 2009, Women in African cinema: An aesthetic and thematic analysis of film making by women in francophone West Africa and Lusophone and Anglophone Southern Africa, PhD thesis, University of Stirling.

Blenkinsopp, J., 1995, Sage, priest, prophet. Religious and intellectual leadership in ancient Israel, Westminster John Knox Press, Louisville, KY.

Bricault, L., 2001, Atlas de la diffusion des cultes/siaques (IVe S. AV. J-C. -IVE S. APR. J.-C.), Mémoires de l'academie des inscriptions et belles-lettres, Diffusion de Boccard, Paris.

Broodryk, J., 2007, Understanding South Africa: The Ubuntu way of living, Ubuntu School of Philosophy, Pretoria.

Chidam'modzi, H.F., 1994/5, 'Addressing African Feminism', Journal of Humanities $8(9), 43-53$.

daCosta, J., 2002, 'Can Apophatic theology be applied to goddessing as well as to God?', Feminist Theology 11(1), 82-98. https://doi.org/10.1177/096673500201100109

Deane-Drummond, C., 1997, 'Sophia: The feminine face of God as metaphor for an ecotheology', Feminist Theology 6, 11-31. https://doi.org/10.1177/0966735 09700001602

Douglas, S., 2016, Early Church understandings of Jesus as the female divine. The scandal of the scandal of particularity, Bloomsbury, London.

Dove, N., 1998, 'African womanism: An afrocentric theory', Journal of Black Studies 28(5), 515-538. https://doi.org/10.1177/002193479802800501

Dyrness, W.A., 1990, Learning about theology from the third world, Zondervan, Grand Rapids, MI.

Eisler, R.T., 1988, The chalice and the blade, Harper, San Francisco, CA.

Ferguson, M., 1995, Women and religion, Prentice Hall, Englewood Cliffs, NJ.

Gilligan, C. \& Rogers, A., 1993, 'Refraining daughtering and mothering: A paradigm shift in psychology', in K.M.G. Schrears, L. Woerton \& J. Van Mens-Verhulst (eds.), Daughtering and mothering: Female subjectivity reanalysed, pp.110-121, Routledge, London.
Goodenough, E.R., 1935, By light, light: The mystic gospel by Hellenistic Judaism, Yale University Press, New Haven, CT.

Hardy, S.B., 2009, Mothers and others: The evolutionary origins of mutua understanding, Belknap Press of University of Harvard Press, Cambridge, MA.

Hudson-Weems, C., 1998, Africana womanism: Reclaiming ourselves, Bedford, Troy, MI.

Iseke, C. \& Uzodeke, U.O., 2011, 'Towards an indigenous model of conflict resolution: Reinventing women's roles as traditional peacebuilders in neo-colonial Africa' viewed 07 July 2015, from http://www.ajol.info/index.php/ajcr/article/viewFile/ $69832 / 57912$

Isichei, E., 2005, The religious traditions of Africa: A history, Westport, London.

Johnson, E., 1992, She who is: The Mystery of God in feminine theological discourse, Crossroad, New York.

Jordan, J.V., Kaplan, A., Miller, J.B., Stiver, I. \& Surrey, J., 1991, Women's growth in connection: Writings from the Stone Center, Guilford Press, New York.

Keller, C., 1991, 'Towards an emancipatory wisdom', in D.R. Griggin \& J.C. Hough (eds.), Theology and university: Essays in Honor of John B Cobb, Jr., pp. 125-147, State University of New York Press, Albany, NY.

Koester, H., 1982, Introduction to the New Testament, volume one: History, culture, and religion of the Hellenistic age, Fortress Press, Philadelphia, PA.

Koka, K.K., 2002, Afrikology, Gauteng Department of Social Development, Johannesburg.

Krog, A., 2008, 'This thing called reconciliation...Forgiveness as part of an interconnectedness-towards-wholeness', South African Journal of Philosophy 27(4), 354-366. https://doi.org/10.4314/sajpem.v27i4.31524

LiDonnici, L.R., 1992, 'The images of Artemis Ephesia and Greco-Roman Worship: A reconsideration', The Harvard Theological Review 85(4), 389-415.

Maclntyre, A., 1966, A short history of ethics, Routledge \& Kegan Paul, London.

MacIntyre, A., 1984, After virtue: A study in moral theory, 2nd edn., University of Notre Dame, Notre Dame.

Masenya, (ngwanaMphahlele) M., 1997, 'Redefining ourselves: A bosadi approach', Old Testament Essays 10(3), 439-448.

Meeks, W., 1993, The origins of Christian morality: The first two centuries, Yale University, New Haven, CT.

Mikell, G. (ed.), 1997, African feminism: The politics of survival in sub-Saharan Africa University of Pennsylvania Press, Philadelphia, PA.

Mouton, E., 2014, 'Reimagening ancient household ethos? On the implied rhetorical effects of Ephesians 5:21-33', Neotestamentica 48(1), 163-185.

Muthien, B., 2008, 'The KhoeSan and partnership: Beyond patriarchy and violence', MA thesis, Department of Political Science, University of Stellenbosch.

Muwati, I., Gambahaya, Z. \& Gwekwerere, T., 2011, 'Africana womanism and African proverbs: Theoretical grounding of mothering/motherhood in Shona and Ndebele Cultural Discourse', Western Journal of Black Studies 35(1), 1-8.

Njoroge, N.J., 2005, 'A new way of facilitating leadership: Lessons from African Women Theologians', Missiology: An International Review 23(1), 29-46. https:// doi.org/10.1177/009182960503300104

Nnaemeka, O. (ed.), 1997, The politics of (M)Othering: Womanhood, identity and resistance in African literature, Routledge, London.

Nwoye, M.A.C., [s a], 'Role of women in peace building and conflict resolution in African Traditional Societies: A selective review', viewed 07 July 2015, from http:// www.afrikaworld.net/afrel/chinwenwoye.htm

Okonjo, K., 1976, 'The dual-sex political system in operation: Igbo women and community politics in Midwestern Nigeria', in N.J. Hafkin \& E.G. Bay, (eds.) Women in Africa: Studies in social and economic change, pp. 45-58. Stanford University Press, Stanford, CA.

Oyěwùmi, O., 2003, 'Introduction: Feminism, sisterhood, and other foreign relations', in O. Oyěwùmi (ed.), African women and feminism: Reflecting on the politics of sisterhood, pp. 1-24, Africa World Press, Trenton, NJ.

Rafferty, A., 2001, 'Sophia and the cosmic dance', FT 27, 102-115.

Robinson, J.M., 1975, 'Jesus as Sophos and Sophia: Wisdom tradition and the Gospels', in R.L. Wilken (ed.), Aspects of wisdom in Judaism and early Christianity, pp. 1-16, University of Notre Dame Press, Notre Dame.

Schüssler-Fiorenza, E., 1975, 'Wisdom mythology and the Christological hymns of the New Testament', in R.L. Wilken (ed.), Aspects of wisdom in Judaism and early Christianity, pp. 17-41, University of Notre Dame Press, Notre Dame.

Schüssler-Fiorenza, E., 1994, Jesus. Miriam's child, Sophia's prophet. Critical issues in feminist Christology, SCM Press, London.

Schüssler-Fiorenza, E., 2009, Towards a feminist wisdom spirituality of justice and well-being, NhandutiEditora, Sao Bernardo do campo, Brazil.

Schüssler-Fiorenza, E., 2011, Transforming vision: Explorations in feminist the*logy, Fortress, Minneapolis, MN.

Slesinski, R., 1984, Pavel Florensky: A metaphysics of love, St Vladimir's Seminary Press, Crestwood, MO. 